\title{
ANALISIS PERTUMBUHAN EKONOMI DALAM PENENTUAN BASIS EKONOMI, ISU KETIMPANGAN DAN LINGKUNGAN DI JAWA BARAT PERIODE 2010-2019
}

\author{
Muhamad Ferdy Firmansyah" ${ }^{1)}$ \\ Universitas Siliwangi ${ }^{1}$ \\ Email: muhamadferdy77@gmail.com ${ }^{1}$
}

\begin{abstract}
ABSTRAK
Pembangunan ekonomi dan pertumbuhan ekonomi menjadi dua agenda analisis ekonomi yang utama untuk mewujudkan kesejahteraan. Dalam menganalisis pembangunan dan pertumbuhan ekonomi salah satu teori yang dapat menjelaskannya adalah mengenai kurva Kuznets $\mathbf{U}$ terbalik. Dalam praktiknya kurva Kuznets $\mathbf{U}$ terbalik dapat menganalisis isu ketimpangan dan isu lingkungan. Maka dari itu penelitian ini dilakukan untuk menemukan posisi ekonomi basis Provinsi Jawa Barat dan menemukan implikasi hipotesis kurva Kuznets $U$ terbalik dalam ketimpangan dan lingkungan di Jawa Barat. Penelitian ini menggunakan data sekunder dengan pendekatan metode kuantitatif. Metode yang digunakan yaitu Indeks Williamson, analisis Shift Share, analisis Location Quotient dan Tipologi Klassen. Didapatkan hasil bahwa basis ekonomi Provinsi Jawa Barat mulai bergeser dari sektor pertanian kepada sektor industri dan jasa. Hipotesis kurva Kuznets untuk isu ketimpangan menunjukan bahwa pertumbuhan ekonomi di Provinsi Jawa Barat dapat menurunkan ketimpangan. Di sisi lain, hipotesis kurva Kuznets untuk isu lingkungan menunjukan peningkatan pertumbuhan ekonomi di Provinsi Jawa Barat akan juga meningkatkan pencemaran lingkungan. Diharapkan Pemerintah Daerah Provinsi Jawa Barat dapat membentuk kebijakan publik yang dapat mendorong pertumbuhan ekonomi yang berkualitas.
\end{abstract}

Kata Kunci: Pertumbuhan, Pembangunan, Ekonomi, Jawa Barat, Kuznets

ABTRACT

Economic development and economic growth are the two main economic analysis agendas to achieve prosperity. In analyzing development and economic growth, one theory that can explain it is the inverted Kuznets $U$ curve. In practice the inverted Kuznets $U$ curve can analyze inequality and environmental issues. Therefore this research was conducted to find the economic position of the base of West Java Province and to find the implications of the inverted Kuznets $U$ curve hypothesis in inequality and the environment in West Java. This study uses secondary data with a quantitative method approach. The methods used are Williamson Index, Shift Share analysis, Location Quotient analysis and Klassen Typology. The results showed that the economic base of West Java Province began to shift from the agricultural sector to the industrial and service sectors. The Kuznets curve hypothesis for the issue of inequality shows that economic growth in West Java Province can reduce inequality. On the other hand, the Kuznets curve hypothesis for environmental issues shows that an increase in economic growth in West Java Province will also increase environmental pollution. It is hoped that the Regional Government of West Java Province can form public policies that can encourage quality economic growth.

Keywords: Growth, Development, Economic, West Java, Kuznets 


\section{PENDAHULUAN}

Pertumbuhan ekonomi (economic growth) dan pembangunan ekonomi (development of economic) menjadi dua topik yang sering dibahas dalam kajian ilmu ekonomi. Pertumbuhan ekonomi menjadi salah satu asumsi dalam kebijakan fiskal dan moneter di Indonesia. Hal ini dikarenakan pertumbuhan ekonomi memiliki analisis keterukuran yang detail pada setiap sektor sehingga dapat mewujudkan kepastian ekonomi. Disisi lain walaupun pertumbuhan ekonomi digunakan sebagai asumsi dan menjadi tolak ukur suatu negara dalam melihat kondisi perekonomian, kelemahan terdapat pada sisi perubahan. Hal ini terlihat bahwa pertumbuhan ekonomi belum tentu dapat menurunkan ketimpangan dan kemiskinan atau pertumbuhan ekonomi belum tentu dapat menurunkan pencemaran lingkungan yang diakibatkan bahwa PDB tidak menghitung kesejahteraan, hal ini menyebabkan bahwa indicator pertumbuhan tidak dapat langsung merepresentasikan pembangunan yang baik (Tietenberg and Lewis 2015). Maka konsep pembangunan ekonomi muncul dengan memasukan aspek perubahan, hal ini diukur utamanya melalui Indeks Pembangunan Nasional yang mengukur bagian pendidikan, kesehatan dan daya beli.

Dalam ukuran pertumbuhan ekonomi pada tingkat nasional digunakan Produk Domestik Bruto (PDB, bahasa inggris: GDP/Gross Domestic Product) sedangkan untuk tingkat provinsi adalah Produk Domestik Regional Bruto (PDRB). Terdapat sejumlah sektor yang disediakan dalam data PDB maupuan PDRB ini. Kenaikan output tahun sekarang dan dibandingkan dengan tahun sebelumnya dapat dianalisis untuk mengukur pertumbuhan ekonomi. Pertumbuhan ekonomi menjadi kebijakan utama yang objektif, hal ini dikarenakan bahwa kebanyakan ukuran penanganan kemiskinan dan masalah social lainnya dapat diatas oleh pertumbuhan ekonomi sebagai suatu representasi kesejahteraan (Perman, et al. 2003). Selain itu Brundtland dalam Perman et al. (2003) menyatakan bahwa pertumbuhan dapat mampu untuk mendukung pembaruan lingkungan melalui penghematan sumber daya, pengurangan material tidak ramah lingkungan secara global sehingga modal dapat direproduksi sebagai modal yang lbeih berkelanjutan. Dalam dalam pengendalian isu pencemaran lingkungan di Jawa Barat masih terkendala atas bebas akses data sehingga padanan identifikasi pencemaran masih bertolak pada skala nasional. Hal ini menjadi dua hal yang perlu diteliti, bahwa ketimpangan dan pencemaran lingkungan di Provinsi Jawa Barat apakah akan menunjukan perbaikan dari pertumbuhan ekonomi Provinsi Jawa Barat yang terus menaik.

Provinsi Jawa Barat menjadi provinsi yang memiliki kompleksitas pembangunan ekonomi, yaitu dari besarnya jumlah penduduk, besarnya sentra industri, pertambangan dan jasa. Provinsi Jawa Barat menjadi provinsi yang strategis dalam pembangunan ekonomi nasional diantaranya terdapat pusat-pusat industri di Kabupaten Karawang, Kabupaten Bogor dan Kabupaten Purwakarta. Terdapat sejumlah wadukwaduk PLTA yang termasuk terbesar di Indonesia (Jatiluhur). Selain itu Provinsi Jawa Barat menjadi provinsi tujuan wisata domestik dan internasional seperti pantai (pelabuhan ratu, pangandaran), perbelanjaan (Kota Bandung) dan adat istiadat (kampung naga di Tasikmalaya dan kampung dukuh di Ciamis). Potensi yang tersebar di segala sektor membuat Jawa Barat secara teoritis dan teknikal analitis memiliki potensi membentuk basis ekonomi yang kuat diberbagai sektor. Isu ketimpangan dan pencemaran lingkungan di Provinsi Jawa Barat menjadi salah satu isu strategis yang 
terus dibahas untuk ditanggulangi. Dari mulai tingkat kemiskinan yang tinggi disejumlah daerah di Provinsi Jawa Barat (Kota Tasikmalaya dan Kabupaten Tasikmalaya) sampai isu pencemaran lingkungan di sepanjang sungai citarum.

Pentingnya penelitian mengenai ekonomi basis ini merujuk pada bahwa setiap perlunya perencanaan pembangnan sektoral untuk lebih mengoptimalkan pertumbuhan ekonomi dan pembangunan ekonomi di Jawa Barat. Hal ini dapat ditemukan melalui analisis ekonomi basis menggunakan pendekatan Indeks Williamson, analisis Shift Share, analisis Location Quotient dan tipologi Klassen. Selain menemukan sektor strategis untuk dikembangkan kita perlu memahami kaitan dari peningkatan pembangunan dan pertumbuhan sektor-sektor basis ini apakah dapat turut membantu untuk menurunkan ketimpangan serta perbaikan lingkungan. Maka digunakan pendekatan analisis hipotesis kurva Kuznets U terbalik untuk mengidentifikasi apakah pertumbuhan ekonomi yang telah dicapai oleh provinsi Jawa Barat dapat mampu turut serta menurunkan angka ketimpangan dan pencemaran lingkungan.

\section{Pertumbuhan dan Pembangunan Ekonomi}

Dalam analisis pertumbuhan dan pembangunan ekonomi menggunakan Produk Domestik Bruto (PDB, bahasa inggris; GDP/Gross Domestic Product). Pertumbuhan ekonomi diartikan secara luas sebagai tambahan output yang bertambah lebih besar tahun sekarang bila dibandingkan dengan tahun yang lalu, atau secara teknikal PDRB riil suatu tahun denga PRDB riil tahun sebelumnya (Sukirno, 2004). Tujuan utama negara berkembang adalah pertumbuhan ekonomi dan pembangunan ekonomi, dimana negara yang tumbuh perekonomiannya tidak tentu memiliki perbaikan dalam pembanguan ekonomi (Nafziger, 2005).

$$
\text { Economic Growth } \rightarrow E G=\frac{G D P_{t}-G D P_{t-1}}{G D P_{t-1}}
$$

Dalam Mourad dan Trabulsi (2019) menggambarkan dalam perspektif ekonomi bahwa produk domestik bruto memberikan dampak positif terhadap household final consumption expenditure $\left(H F C E_{t}\right)$, penawaran uang $\left(M_{l t}\right)$, inflasi dengan ukuran consumer price index $\left(C P I_{t}\right)$, suku bunga $\left(\right.$ rir $\left._{t}\right)$ dan variabel lain. Adapun hubungan spesifik antara GDP, pengeluran dan gross domestic savings $\left(G D S_{t}\right)$ yaitu sebagai berikut:

$$
\begin{gathered}
\text { income identity } \rightarrow G D P_{t}=G D S_{t}+H F C E_{t}+G F C E_{t} \\
G D P_{t} \text { diharga konstantakan } \rightarrow G D P_{t}=G D P_{0}(1+r)^{t}
\end{gathered}
$$

Pembangunan ekonomi (economics development) bila dikategorikan sebagai studi ilmu, merupakan studi ilmu yang mencakup kajian ekonomi yang luas dalam efisiensi alokasi sumber daya produktif yang langka, kesinambungan pertumbuhan ekonomi serta memberikan perhatian pada mekanisme sosial yang ada pada ranah publik dan swasta (Todaro \& Smith, Pembangunan Ekonomi di Dunia Ketiga, 2003). Pembangunan ekonomi merujuk pada pertumbuhan ekonomi yang disertai perubahan distribusi dan struktur ekonomi (Nafziger, 2005). Hal ini menyebabkan bahwa 
pertumbuhan ekonomi memberikan gambaran analitis dan teknikal pertama pada perkembagnan ekonomi suatu wilayah dan kemudian dapat dianalisis lebih lanjutan apakah terjadi pembangunan ekonomi setelah terjadi pertumbuhan ekonomi. Pembangunan ekonomi memiliki paduan adanya pertumbuhan dan perubahan struktur ekonomi menuju tahapan yang lebih baik, sehingga melihat pula aspek sosial ekonomi dalam masyarakat (kemiskinan, pengangguran, perilaku daya beli dsb) sedangkan pertumbuhan ekonomi menitikberatkan secara kuantitatif pada kenaikan output secara analitis dan menghiraukan aspek sosial.

\section{Teori Regional, Perencanaan Wilayah dan Ekonomi Basis}

Ekonomi regional menjelaskan mengenai karakteristik spasial dalam sistem perekonomian yang digunakan (Hoover \& Giarratani, 2020). Kajian ekonomi regional meliputi sejumlah pertanyaan mengenai "what is, where is and why so?". Pertama, "what is?" merujuk pada apa tipe aktivitas ekonomi yang dilakukan; yaitu meliputi berbagai sektor (pretanian, pertambangan dsb) dalam produksi, distribusi, konsumsi yang dilakukan oleh perusahaan, pemerintah dan konsumen. Kedua, "where is?" merujuk pada lokasi dari aktivitas ekonomi yang dipilih; hal ini mendalami mengenai konsentrasi lokasi, kemudahan akses distribusi, jarang bahan mentah. Ketiga, "why so?" merujuk pada intrepetasi dari bagaimana asumsi-asumsi keterbatasan kemampuan ekonomi dalam merespon pasar. Sehingga ekonomi regional pada kedudukannya dapat menjadi studi yang aplikatif dalam mengkaji proses dalam pemanfaatan sumber daya alam yang berkelanjutan dan menghasilkan output nilai yang menguntungkan bisnis, masyarakat dan pendatang (Stimson, Stough, \& Roberts, 2006) .

Perencanaan merupakan suatu cara dan rumusan yang teratur dan sistematis, sesuai menurut Alexander dalam Djunaedi (2015) menyebutkan kegiatan masyarakat dan organisasi dapat menimbulkan pengembangan strategi terkait tindakan di masa depan untuk mencapai seperangkat tujuan yang diinginkan. Menurut Djunaedi (2015) memberikan tiga pernyataan mengenai definisi perencanan yaitu (1) perencanan terkait dengan pengalokasian sumber daya yang tersedia, (2) perencanaan perlu mampu mengatasi dinamika dan kompleksitas wilayah dan kota, (3) perencanaan wilayah dan kota bersifat publik dan (4) perencanaan wilayah dan kota bertujuan untuk mewujudkan kesejahteraan bagi masyarakat. Keterkaitan antara perencanaan, regional dan pembangunan erat kaitannya dengan perlunya memahami perencanaan regional dengan skema sumber eksternal (ekspor, grants, investor asing dan transfer pendaptan) dan skema sumber internal (asset, dividen, tabungan, tenaga kerja dan modal sosial) (Stimson, Stough, \& Roberts, 2006). Dalam hal ketidaktentuan perencanaan, Tarigan (2006) menyebutkan perencanaan harus dapat mengetahui dan menganalisis kondisi saat ini, meramalkan perkembangan berbagai faktor non controllable yang relevan, memperkirakan faktor-faktor pembatas, menetapkan tujuan dan sasaran yang diperkirakan dapat dicapai, menetapkan langkah-langkah untuk mencapai tujuan tersebut, serta menetapkan lokasi dari berbagai kegiatan yang akan dilaksanakan.

Menentukan ekonomi basis perlu memperhatikan konsep regional yang baik serta perencanaan yang memiliki koordinasi dan ketepatan sasaran yang jelas. Teori basis ekonomi (economics based theory) dapat didefinisikan sebagai peningkatan dari pertumbuhan suatu regional akibat adanya sektor dominan yang mendorong 
pertumbuhan ekonomi regional (Tarigan, 2005). Adapun sektor dominan yang mendorong pertumbuhan ekonomi adalah sektor basis, ini berarti bahwa dalam perekonomian regional terdapat sektor basis dan sektor non-basis, dimana sektor yang bersifat endogenous (tidak bebas tumbuh) hayan bergantung pada pengaruh keadaan ekonomi secara keseluruhan (Tarigan, 2005). Dalam melihat ekonomi basis dapat dilakukan melalui analisis Indeks Williamson, Analisis Location Quotient dan Analisis Shift Share (Saputra, 2016).

\section{Kurva Kuznets dalam Ketimpangan Ekonomi}

Ketimpangan ekonomi terjadi akibat dari ketidakmerataan pendapatan. Di negara berkembang, pertumbuhan ekonomi tumbuh namun tidak dapat meningkatkan secara signifikan kenaikan pendapatan masyarakat, hal ini diakibatkan oleh pertumbuhan ekonomi yang terjadi hanya di nikmati oleh rumah tangga tertentu sehingga terjadi gap pendapatan (Oyvat, 2015). Hipotesis Kuznets menjelaskan bahwa kenaikan pertumbuhan ekonomi menurunkan ketimpangan dan kemiskinan dalam jangka waktu tertentu (atau disebut sebagai batas turning point). Kurva Kuznets memainkan peran analisis masalah dalam variabel endogen ekonomi yaitu teknologi, populasi, institusi (Syrquin, 2005) serta berdampak pada stabilitas politik dan peningkatan skala demokratisasi politik (demokratisasi ini mendukung perubahan kebijakan dalam redistribution dan reduce inequality) (Acemoglu \& Robinson, 2002). Gambar 1. Kurve Kuznets membentuk "U terbalik"

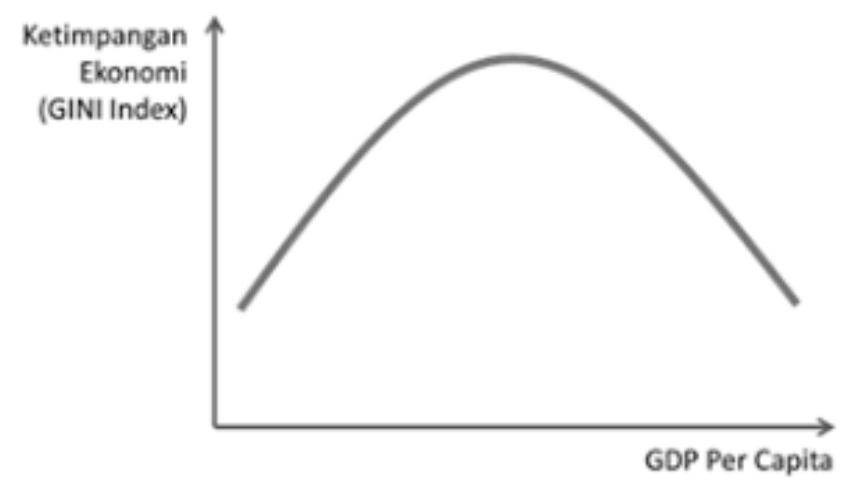

Sumber: Todaro dalam Saputra (2016)

Saputra (2016) menemukan bahwa hipotesis U terbalik berlaku di Jawa Barat pasca Orde baru, melalui hubungan terbalik antara Indeks Williamson dengan PDRB per kapita Jawa Barat. Hal ini menunjukan adanya harapan bahwa pertumbuhan ekonomi di Jawa Barat dapat memberikan kontribusi pada penurunan kemiskinan dan ketimpangan antar wilayah. Adapun sektor basis yaitu sektor pertanian, industri pengolahan, konstruksi, perdangan dan akomodasi. Hal ini ditemukan pula dalam Hilmi, Hamzah dan Syahnur (2014) bahwa sektor basis provinsi Jawa Barat adalah pada sektor pertanian, industri pengolahan, perdagangan, pertambangan dan listrik gas dan air minum. Selanjutnya secara sektoral, pertanian sebagai sektor basis dalam Widianingsih dan Suryantini (2015) bahwa pertanian di bidang sub sektor tanaman bahan makanan dan holtikultura memiliki basis disebagian kab/kota basis pertanian serta sub sektor kehutanan dan peternakan yang memiliki daya saing yang baik dan berada pada kategori 
maju tapi tertekan. Dalam penelitian Suhartono dan Kurniawati (2013) menemukan bahwa sektor basis Jawa Barat adalah industri pengolahan, listrik dan air bersih, perdagangan, hotel dan restoral serta pengangkutan dan komunikasi. Selain itu, ditemukan bahwa pada periode sektor-sektor basis tersebut memiliki pertumbuhan yang cepat dibandingkan pertumbuhan nasional, sehingga berkembang dengan pesat menjadi pendorong pertumbuhan ekonomi Jawa Barat. Kaitan PDRB dan ketimpangan ekonomi di Jawa Barat menunjukan angka perbaikan dengan hipotesis kurva Kuznets U-terbalik yang terwujud secara analisis.

\section{Kurva Kuznets dalam Lingkungan}

Environmental Kuznets Curve (EKC) merupakan kurva yang menunjukan hubungan antara pertumbuhan ekonomi dan emisi CO2 yang menyatakan bahwa akan terjadi penurunan emisi $\mathrm{CO} 2$ dalam batas turning point tertentu yang akan menyebabkan pertumbuhan ekonomi berkontribusi dalam penurunan emisi CO2 (Perman, Ma, McGilvray, \& Common, 2003). Kurva ini menujukan bahwa terjadi hubungan kausalitas antara pertumbuhan ekonomi dan emisi CO2 yang akan membentuk kurva U-terbalik (Aydin \& Esen, 2017). Hal ini terjadi melalui analisis hubungan dengan menggunakan sejumlah observasi dengan plot variabel empiris terhadap degradasi lingkungan dan pertumbuhan ekonomi utamanya dalam melihat nilai dari perkemangan emisi CO2 (Tietenberg \& Lewis, 2015). Analisis dari Environmental Kuznets Curve (EKS) memiliki persamaan dalam menganalisis hubungan dari pendapatan per kapita dan ketimpangan pendapatan yang dipelopori oleh Simon Kuznets pada tahun 1955 yaitu menganalisis fenomena yang memiliki titik optimum (turning point) sehingga ketika fenomena melewati titik optimum tersebut maka akan menghasilkan hubungan berkebalikan (Hussen, 2005). Disisi lain, diluar kritik atas teori dan hipotesis ini namun dalam ekonomi pertumbuhan ekonomi (maupun pembangunan ekonomi) merupakan hal yang lebih baik dilakukan daripada tidak sama sekali bagi lingkungan (Hussen, 2005).

$$
\ln (\mathrm{E} / \mathrm{P})_{i t}=\alpha_{i}+\gamma_{t}+\beta_{1} \ln (\mathrm{GDP} / \mathrm{P})_{i t}+\beta_{1}(\ln (\mathrm{GDP} / \mathrm{P}))^{2}{ }_{i t}+\varepsilon_{i t}
$$

Dalam penelitian Nikensari, S. I., Destilawati, S., \& Nurjanah, S. (2019) meneliti hipotesis EKC di negara berpenghasilan tinggi (high income countries) dan negara berpenghasilan menengah bawah (lower middle income), indikasi bahwa negaranegara sampel yang telah melalui turning point diindikasikan dapat menurunkan emisi $\mathrm{CO} 2$, ditemukan bahwa bagi negara berpenghasilan tinggi (high income countries) akan mampu untuk menurunkan emisi $\mathrm{CO} 2$ setelah mencapai turning potint sedangkan bagi negara berpenghasilan menengah bawah (lower middle income) tetap tidak dapat menurunkan emisi $\mathrm{CO} 2$ walaupun telah melampuai turning point. Dalam penelitian Firdaus (2017) menemukan bahwa kenaikan populasi penduduk dapat meningkatkan emisi $\mathrm{CO} 2$, hal ini diakibatkan oleh adanya peningkatan permintaan akan konsumsi energy.

Konsumsi energi memiliki pengaruh yang signifikan ditemukan oleh Yustisia dan Sugiyanto (2014) menyatakan bahwa negara middle development countries yang memiliki karakteristik kurva U-terbalik, sedangkan bagi negara-negara high 
development countries serta low development coutnries justru diindikasikan tidak memiliki titik balik atau kerusakan lingkungan terus meningkat. Sedangkan menurut Arista dan Amar (2019) menemukan bahwa terdapat hubungan kausalitas antara pertumbuhan ekonomi dan emisi CO2 di negara Asia Tenggara, sehingga peningkatan pertumbuhan ekonomi di negara Asia Tenggara akan tentu meningkatkan emisi CO2. Hubungan kausalitas antara pertumbuhan ekonomi dan emisi $\mathrm{CO} 2$ pun dikuatkan melalui penelitian Fasika dan Yuliadi (2018) yang meneliti negara-negara di Asia Tenggara menemukan bahwa Hasil penelitian menunjukkan bahwa pada negara-negara ASEAN periode 2005-2015 terindikasi hipotesis Environmental Kuznets Curve (EKC) pada industrial enonomics yang mana jumlah Emisi CO2 dan GDP per kapita bersamaan terus mengalami peningkatan dan belum mencapai titik balik. Dalam skala provinsi, Jawa Barat mesti mampu berkontribusi pada nasional untuk pengendalian emisi.

Gambar 2. Hipotesis Environmental Kuznets Curve (EKC)
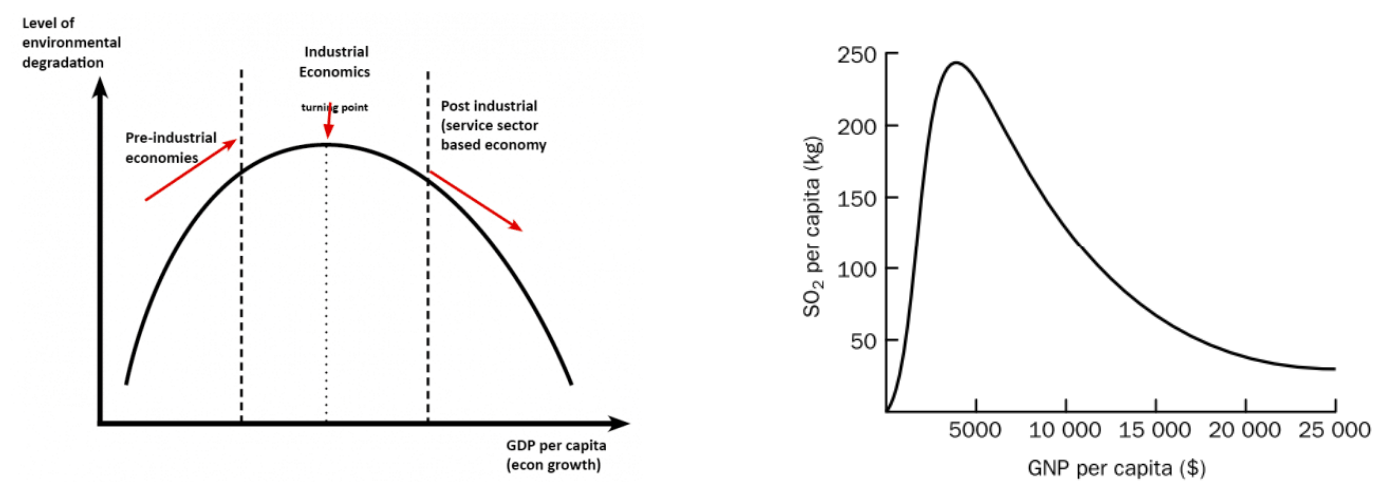

Sumber: Pettinger (2019) dan Panayoutou dalam Perman dkk. (2003)

Bila ditarik garis besar maka kurva Kuznets memiliki pola bahwa "suatu pertambahan variabel ekonomi tertentu yang berkelanjutan akan mendorong penurunan variabel ekonomi terpengaruh lainnya secara berkelanjutan pula”. Seperti untuk kurva Kuznets untuk ketimpangan dan kemiskinan menyatakan bahwa kenaikan pertumbuhan berkelanjutan akan dapat menurunkan ketimpangan dan kemiskinan. Selanjutnya disebutkan pula bahwa kurva lingkungan Kuznets (selanjutnya disebut Environmental Kuznets Curve) menyatakan bahwa kenaikan pertumbuhan berkelanjutan yang berkualitas akan dapat menurunkan pencemaran lingkungan dalam emisi gas rumah kaca.

\section{METODE PENELITIAN}

Metode penelitian yang digunakan dalam penulisan ini adalah metode campuran, yaitu dengan membentuk penelitian yang proporsional, sistematis dan efektif dalam analisis kuantitatif untuk menuju hasil yang diharapkan (Sugiyono 2013). Metode kuantitatif digunakan dengan rancangan analisis data. Metode kuantitatif digunakan dalam kerangka determinisme (asumsi filosofis pospositivis) yaitu menguji hubungan variabel uji guna menjawab hipotesis atau rumusan masalah yang dibentuk (Creswell 2017). Data yang digunakan dalam penelitian ini adalah data sekunder yang berasal dari Badan Pusat Statistik dan World Bank Development Indicator. Data yang digunakan 
dalam rentang periode 2010-2019. Adapun data PDB Indonesia dalam satuan miliar rupiah, PDRB Jawa Barat dalam satuan miliar rupiah, data emisi gas rumah kaca (CO2, energi, FOLU, limbah, IPPU, pertanian dan kebakaran hutan) dalam satuan ribuan ton. Jumlah penduduk dalam satuan jiwa.

Dalam penelitian yang pertama akan mencari ekonomi basis secara sektoral dalam isu ketimpangan ekonomi di Provinsi Jawa Barat. Analisis yang digunakan untuk tingkat provinsi secara pusat adalah Indeks Williamson, analisis regresi non linear model kuadratik, analisis location quotient dan analisis shift share. Selanjutnya sebagai analisis untuk tingkat kabupaten dan kota secara daerah maka digunakan analisis tipologi klassen. Perbedaan pengambilan keputasan ini untuk mempermudah penarikan kesimpulan sehingga analisis basis provinsi Jawa Barat dapat lebih mudah dianalisis secara sistematis, proporsional dan efektif. Berikut adalah formula untuk menentukan Indeks Williamson (M. Kuncoro, 2004; Nurpita dan Nastiti, 2016):

$$
I W=\frac{\sqrt{\sum_{i=1}^{n}\left(y_{i}-y\right)^{2}}\left(f_{i} / n\right)}{y}, \text { dimana } 0<V_{w}<1
$$

Bentuk umum untuk melakukan estimasi hipotesis kurva kuznets dengan regresi non linear model kuadratik yaitu sebagai berikut (Gujarati 2010; Saputra 2016):

$$
I W=\alpha+\beta_{1} Y+\beta_{2} Y^{2}+\epsilon
$$

Keterangan:

IW $=$ Indeks Williamson untuk wilayah i pada tahun $\mathrm{t}$

$Y \quad=\quad$ PDB per kapita untuk wilayah i pada tahun $\mathrm{t}$

$Y^{2}=$ PDB per kapita kuadrat untuk wilayah i pada tahun $\mathrm{t}$

$\epsilon \quad=\quad$ Eror term

$\alpha=$ Konstanta

$\beta_{1}, \beta_{2}=$ Koefisien

Selain kurva Kuznets menggambarkan adanya pola penurunan ketimpangan dan kemiskinan dari tiap tambahan berkelanjutan pada pertumbuhan ekonomi, kurva ini pun memiliki paradigma pemikiran yang diterapkan pada kurva yang diberi nama Environmental Kuznets Curve (EKC). Dalam penelitian kedua ini akan menentukan hipotesis U terbalik pada isu lingkungan. Untuk mengetahui proyeksi penurunan maka digunakan regresi non linear model kuadratik dengan persamaan regresi yaitu sebagai berikut (Nikensari, Destilawati dan Nurjanah 2019; Gujarati 2010) :

$C O 2=\alpha+\beta_{1} P D B+\beta_{2} P D B^{2}+\epsilon$

$\mathrm{CO} 2=$ Emisi untuk wilayah i pada tahun $\mathrm{t}$

$P D B=$ PDB per kapita untuk wilayah i pada tahun $\mathrm{t}$

$P D B^{2}=$ PDB per kapita kuadrat untuk wilayah i pada tahun $\mathrm{t}$ 


$$
\begin{array}{lll}
\epsilon & = & \text { Eror term } \\
\alpha & = & \text { Konstanta } \\
\beta_{1}, \beta_{2}, \beta_{3} & = & \text { Koefisien }
\end{array}
$$

Berdasarkan persamaan diatas, untuk mengestimasi berlakunya hipotesis kurva Kuznets U-terbalik dalam ketimpangan maka didasarkan dengan syarat sebagai berikut:

a. Jika $\beta_{2}<0$, terjadi hubungan berbentuk U-terbalik

b. Jika $\beta_{2}>0$, tidak terjadi hubungan berbentuk U-terbalik

Dalam analisis ini menggunakan perangkat lunak SPSS 26 (baik dalam uji regresi non linear model kuadratik di penelitian pertama dan penelitian kedua). Penelitian pertama dan kedua mengambil Confident Interval (CI) yaitu 95\% atau sebesar 0,05. Pengujian signifikansi dan digunakan hipotesis statistika dengan uji t dan uji F yang bersifat komplementer atau bernotasi $P\left(H_{a}\right)=1-P\left(H_{0}\right)=P\left(\widetilde{H}_{0}\right)$, dimana $H_{a}$ merupakan hipotesis dengan perbedaan dan $H_{0}$ merupakan hipotesis dengan tidak ada perbedaan (Somantri and Muhidin 2014)

Dalam melakukan analisis basis atau potensial dikembangkan pada suatu daerah maka dapat digunakan analisis Location Quotient. Analisis ini memberikan perbandingan relatif antar sektor melalui wilayah tertentu dengan wilayah pembanding. Dengan dilakukannya perbandingan relatif maka akan ditemukan sektor basis yang dapat diandalkan dalam pertumbuhan ekonomi dan optimalisasi pembangunan ekonomi suatu daerah. Berikut adalah formula untuk menentukan Location Quotient (LQ):

Keterangan:

$$
L Q=\frac{S i / S}{N i / N}
$$

$$
\begin{array}{ll}
\mathrm{Si} & =\text { Nilai tambah sektor i provinsi } \\
\mathrm{S} & =\text { PDRB Provinsi } \\
\mathrm{Ni} & =\text { Nilai tambah sektor i nasional } \\
\mathrm{N} & =\text { PDB nasional }
\end{array}
$$

Berdasarkan persamaan diatas, untuk menemukan nilai Location Quotient maka didasarkan dengan syarat sebagai berikut:
a. Jika $L Q<0$,
b. Jika $L Q>0$,
c. Jika $L Q=0$,

Dalam menentukan kinerja atau produktivitas kerja perekonomian daerah dapat diukur melalui analisis Shift Share. Analisis ini memberikan gambaran meliputi ukuran outpur sektor-sektor uji dengan dipengaruhi oleh sturktur industry maupun sturktur lokasi (Saputra 2016). Berikut adalah formula untuk menentukan analisis Shift Share: 
Keterangan:

$$
\begin{aligned}
& >D i j=N i j+M i j+C i j \\
& >N i j=E i j \times R n \\
& >M i j=E i j(R i n-R n) \\
& >C i j=E i j(R i j-R i n)
\end{aligned}
$$

Dij = Dampak nyata pertumbuhan ekonomi daerah $(\mathrm{kab} / \mathrm{kota})$ dari pengaruh pertumbuhan nasional (provinsi Jawa Barat)

$\mathrm{Nij}=$ (National Share) pengaruh pertumbuhan ekonomi nasional terhadap perekonomian di suatu daerah

Mij = Pergeseran proporsional (proportional shift) atau pengaruh bauran industri

$\mathrm{Cij}=$ (Differential Shift) pengaruh keunggulan kompetitif suatu sektor tertentu dibandingkan dengan tingkat nasional

Eji $=$ PDRB (output) sektor $\mathrm{i}$

Rij = Tingkat Pertumbuhan sektor $\mathrm{i}$

Rin $=$ Tingkat pertumbuhan sektor i nasional

$\mathrm{Rn}=$ Tingkat pertumbuhan PDRB

Analisis disparitas regional (melalui Indeks Williamson dan uji hipotesis kurva kuznets) dan penentuan sektor ekonomi basis (analisis location quotient dan analisis shift share) dapat menunjukan kinerja pertumbuhan ekonomi pada perekonomian di Jawa barat. Selanjutnya pada tingkat daerah untuk melihat klasifikasi wilayah kabupaten dan kota maka digunakan tipologi klassen. Tipologi Klassen digunakan sebagai ukuran untuk melihat perkembangan pertumbuhan ekonomi wilayah dalam

\begin{tabular}{|c|c|c|}
\hline $\begin{array}{l}\text { PDRB per Kapita (y) } \\
\rightarrow \\
\text { Laju Pertumbuhan (r) } \downarrow\end{array}$ & yi $<$ y & $y i>y$ \\
\hline$r i>r$ & $\begin{array}{l}\text { Kuadran II } \\
\text { Maju tapi tertekan (Retarted } \\
\text { Region) } \\
\qquad y 1<y ; r 1>r\end{array}$ & $\begin{array}{l}\text { Kuadran I } \\
\text { Maju dan tumbuh pesat (Rapid } \\
\text { Growth Region) } \\
\qquad y 1>y ; r 1>r\end{array}$ \\
\hline $\mathrm{ri}<\mathrm{r}$ & $\begin{array}{l}\text { Kuadran III } \\
\text { Terbelakang } \quad \text { (Undeveloped } \\
\text { Region) } \\
\qquad y 1<y ; r 1<r\end{array}$ & $\begin{array}{l}\text { Kuadran IV } \\
\text { Berkembang Cepat (Growing } \\
\text { Region) } \\
\qquad y 1>y ; r 1<r\end{array}$ \\
\hline
\end{tabular}
konteks kuadran. Tipologi Klassen Adapun parameter pengukuran tipologi klassen adalah sebagai berikut:

Tabel 1. Tipologi Klassen

Sumber: Saputra (2016) dan Mukhlis dkk (2018)

Dimana $y 1$ adalah pendapatan per kapita daerah ke-I, $y$ adalah pendepatan per kapita nasional, $r 1$ adalah laju pertumbuhan PDRB daerah ke-I dan $r$ adalah laju 
pertumbuhan PDRB daerah ke i. Kuadran I (maju dan tumbuh pesat) adalah daerah yang mengalami pertumbuhan PDRB dan tingkat pertumbuhan pendatapan perkapita yang tinggi dari rata-rata seluruh daerah. Kuadran II (daerah maju tapi tertekan) adalah daerah yang relative maju namun beberapa tahun terakhir mengalami pelambatan akibat tertekannya laju pertumbuhan sektor tersebut. Kuadran III (relatif tertinggal) adalah daerah yang mempunyai tingkat pertumbuhan dan tingkat pendapatan rata-rata yang rendah dibandingkan daerah lainnya. Kuadran IV (berkembang cepat) adalah daerah yang memiliki potensi untuk mengembangkan sektor-sektornya namun belum dikelola secara lebih efektif dan efisien (Saputra 2016). Dengan adanya ketepaduan analisis antara Indeks Williamson, Analisis Location Quotient, Analisis Shift Share dan Tipologi Klassen maka akan ditemukan ekonomi basis dan ketimpangan ekonomi Provinsi Jawa Barat pada periode 2010-2019.

\section{HASIL DAN PEMBAHASAN}

\section{Pertumbuhan Ekonomi Jawa Barat Periode 2008-2019}

Provinsi Jawa Barat menjadi salah satu provinsi terbesar di Indonesia dalam jumlah penduduk, pertumbuhan industri pengolahan, perdagangan serta transportasi. Sektor-sektor tersebut secara angka kasar memiliki kontribusi yang besar pada pertumbuhan ekonomi Provinsi Jawa Barat hamper 1 dekade lamanya. Pertumbuhan ekonomi Provinsi Jawa Barat memiliki tren positif setiap tahun dengan rata-rata pertumbuhan pada periode 2010-2019 adalah sebesar 5,68\% diatas rata-rata pertumbuhan nasional yang mencapai $5,32 \%$ pada periode yang sama. Secara rentang waktu, pertumbuhan ekonomi Jawa Barat memiliki hubungan dengan pertumbuhan ekonomi Indonesia, sehingga pada rata-rata penurunan periode 2014-2015 pertumbuhan Provinsi Jawa Barat terkontraksi bersamaan dengan terkontraksinya pertumbuhan ekonomi Indonesia.

Gambar 3. Pertumbuhan Ekonomi Indonesia dan Provinsi Jawa Barat Periode 2010-2019

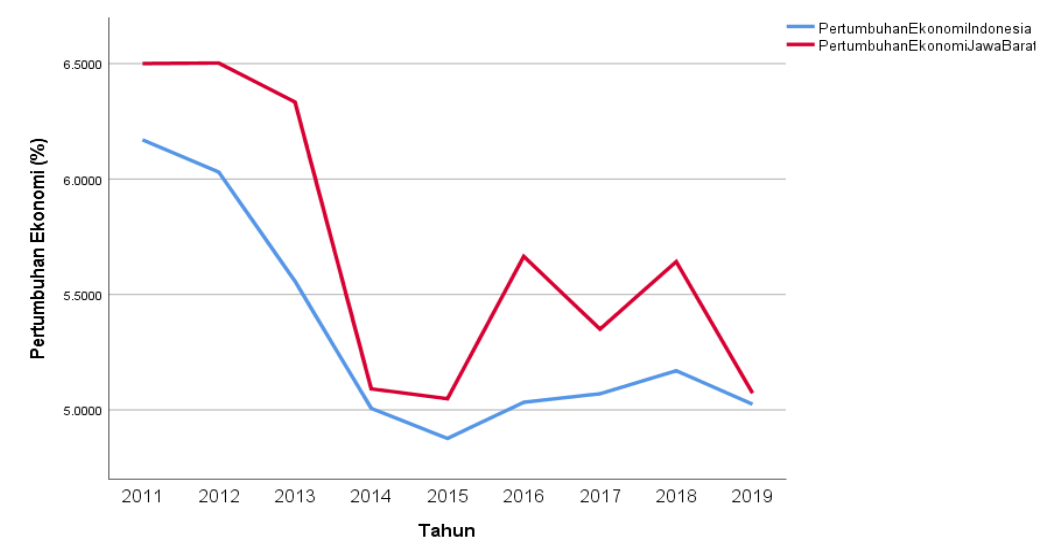

Sumber: Dokumen Penulis

Sepanjang periode 2010-2019 pertumbuhan tertinggi didapatkan oleh Kota Depok dengan rata-rata pertumbuhan ekonomi yaitu 7,62\%. Selanjutnya disusul oleh posisi kedua Kota Bandung (7,60\%), posisi ketiga Kota Bogor (6,19\%), posisi keempat Kabuapten Kuningan (6,18\%) dan posisi kelima diduduki oleh Kabupaten Bandung $(6,07 \%)$. Adapun lima kabupaten atau kota yang memiliki pertumbuhan terendah yaitu 
posisi 27 diduduki oleh Kabupaten Indramayu (2,58\%), posisi 26 Kabupaten Subang $(4,15 \%)$, posisi 25 Kabupaten Garut $(4,87 \%)$, posisi 24 Kabupaten Tasikmalaya $(4,99 \%)$ dan posisi 23 Kabupaten Pangandaran (5,04\%).

\section{Implikasi Hipotesis Kurva Kuznets Dalam Ketimpangan di Jawa Barat}

Hasil dari analisis Indeks Williamson adalah sebagai berikut:

Tabel 2. Hasil Analisis Indeks Williamson

\begin{tabular}{ccccc}
\hline Tahun & $\begin{array}{c}\text { Indeks } \\
\text { Williamson }\end{array}$ & Perubahan & PDRB Jawa Barat & $\begin{array}{c}\text { Populasi Jawa } \\
\text { Barat }\end{array}$ \\
\hline 2010 & 0,710085672 & - & 906685,76 & 43227107 \\
2011 & 0,712313629 & 0,003137589 & 965622,06 & 43938796 \\
2012 & 0,711330612 & $-0,00138003$ & 1028409,74 & 44643586 \\
2013 & 0,714544523 & 0,004518168 & 1093543,55 & 45340799 \\
2014 & 0,705471437 & $-0,01269772$ & 1154391,69 & 46029668 \\
2015 & 0,706271931 & 0,001134693 & 1206891,27 & 46709569 \\
2016 & 0,702246718 & $-0,00569924$ & 1277312,17 & 47379389 \\
2017 & 0,701260319 & $-0,00140463$ & 1350879,84 & 48037827 \\
2018 & 0,702238265 & 0,001394555 & 1430710,19 & 48683861 \\
2019 & 0,691621758 & $-0,0151181$ & 1491705,81 & 49316712 \\
\hline
\end{tabular}

Sumber: Olahan Penulis

Nilai Indeks Williamson menunjukan masih terjadinya ketimpangan di Provinsi Jawa Barat. Dalam hasil analisis terlihat bahwa terjadi tren semakin menurun angka Indeks Williamson, hal ini mengindikasikan terjadinya perbaikan ketimpangan yang terjadi di Provinsi Jawa Barat. Dengan mendapatkan nilai Indeks Williamson dan PDRB Jawa Barat, maka selanjutnya menguji hipotesis kurva Kuznets U terbalik dengan menggunakan regresi non linear model kuadratik. Didapatkan hasil sebagai berikut:

Tabel 3. Hasil Analisis Hipotesis Kurva Kuznets isu Ketimpangan

\begin{tabular}{|c|c|c|c|}
\hline \multirow{2}{*}{ Sampel } & \multicolumn{2}{|c|}{ Nilai Koefisien } & \multirow{2}{*}{ Posisi } \\
\hline & PDB & $\mathrm{PDB}^{2}$ & \\
\hline Indeks Wiliamson & $9,714 \mathrm{E}-8$ & $-5,306 \mathrm{E}-14$ & Terjadi U terbalik \\
\hline
\end{tabular}

Sumber: Olahan Penulis

Hasil uji hipotesis menunjukan bahwa di Provinsi Jawa Barat terbukti terjadi U terbalik pada isu ketimpangan. Hal ini bermakna bahwa pertumbuhan ekonomi di Provinsi Jawa Barat yang berkelanjutan (disertai peningkatan kualitas pertumbuhan) akan mendorong penurunan ketimpangan dan kemiskinan di Provinsi Jawa Barat. Salah satu faktor pendorong ini bahwa sektor-sektor yang menjadi basis dari Provinsi Jawa Barat telah belih dari sektor-sektor yang berorientasi pertanian menjadi industri dan jasa. Sektor yang berorientasi industri dan jasa akan menciptakan distribusi pendapatan yang lebih layak daripada sektor pertanian. Dengan mulai beralihnya sektor basis di 
Provinsi Jawa Barat mengindikasikan bahwa perekonomian di Provinsi Jawa Barat telah masuk fase industrialisasi dan teknologi yang mencirikan suatu provinsi telah menuju perkembangan yang luar biasa dan berkelanjutan.

\section{Basis Ekonomi dan Hipotesis Kurva Kuznets di Provinsi Jawa Barat}

Hasil dari analisis Location Quotient didapatkan bahwa pada periode 2010-2019 Provinsi Jawa Barat memiliki sektor basis yaitu pada sektor 3 (sektor industri pengolahan), sektor 7 (sektor perdagangan besar dan eceran, reparasi mobil dan sepeda motor), sektor 8 (sektor transportasi dan pergudangan) dan sektor 17 (jasa lainnya). Sektor-sektor ini menjadi pendorong terbesar dalam pertumbuhan ekonomi di Jawa Barat. Maka dari itu, pemerintah daerah Provinsi Jawa Barat harus mendorong untuk terciptanya labor insentive (tambahan tenaga kerja) dari sektor-sektor basis ini sehingga dapat membawa penurunan ketimpangan dan kemiskinan.

Adapun dalam analisis sektor basis dan non-basis ini peneliti melihat terdapat tiga sektor yang memiliki angka LQ > 0,8 dan memiliki tren positif (menaik) setiap tahunnya. Penentuan ini digunakan sebagai upaya dalam menemukan sektor-sektor pertumbuhan baru untuk meningkatkan pertumbuhan ekonomi di provinsi Jawa Barat. Sektor tersebut yaitu sektor 5 (sektor pengadaan air, pengelolaan sampah, limbah dan daur ulang), sektor 6 (sektor konstruksi) dan sektor 15 (sektor jasa pendidikan). Ketiga sektor tersebut dapat menjadi bagian dari sektor basis dalam 2-5 tahun mendatang apabila memiliki tren yang terus positif.

Tabel 5. Hasil Analisis Location Quotient dan Rata-Rata Nilai

\begin{tabular}{llll}
\hline \multicolumn{1}{c}{ Sektor Basis } & \multicolumn{2}{c}{ Sektor Non-Basis } & \multicolumn{1}{c}{ Potensial Basis } \\
\hline 1. Sektor 3 $(2,02)$ & 1. Sektor 1 & 8. Sektor 11 & 1. Sektor 5 $(0,87)$ \\
2. Sektor 7 $(1,17)$ & $(0,62)$ & $(0,63)$ & 2. Sektor 6 $(0,82)$ \\
3. Sektor 8 $(1,17)$ & 2. Sektor 2 & 9. Sektor 12 & 3. Sektor 15 $(0,82)$ \\
4. Sektor 17 $(1,21)$ & $(0,31)$ & $(0,40)$ & 4. Sektor 9 $(0,84)$ \\
& 3. Sektor 4 & 10. Sektor 13 & \\
& $(0,46)$ & $(0,22)$ & \\
& 4. Sektor 5 & 11. Sektor 14 & \\
& $(0,87)$ & $(0,61)$ & \\
& 5. Sektor 6 & 12. Sektor 15 & \\
& $(0,82)$ & $(0,82)$ & \\
& 6. Sektor 9 & 13. Sektor 16 & \\
& $(0,84)$ & $(0,66)$ & \\
& 7. Sektor 10 & & \\
& $(0,72)$ & & \\
\hline Sumber: Olahan Penulis & & &
\end{tabular}

Sumber: Olahan Penulis

Selanjutnya analisis shift share didapatkan hasil Dij yang positif yaitu $\mathrm{Rp}$ 915.280,80 miliar rupiah, hal ini menunjukan bahwa perekonomian Provinsi Jawa Barat memiliki kinerja pertambahan nilai absolut yang produktif pada semua sektor. Nilai Cij menggambarkan tingkat kompetitif suatu sektor. Nilai Cij yang positif menunjukan sektor ekonomi yang kompetitif. Dengan pengamatan pada hasil, didapatkan bahwa 
sektor industri pengolahan, disusul sektor informasi dan komunikasi serta sektor perdagangan besar dan eceran, reparasi mobil dan sepeda motor. Ketiga sektor ini memiliki tingkat kompetitif yang tinggi. Namun telihat bahwa nilai Cij sejumlah sektor terdapat pada posisi negatif, yaitu sektor pertanian, kehutanan dan perikanan, disusul sektor negatif yaitu sektor pertambangan dan penggalian serta administrasi pemerintahan, pertahanan dan jaminan sosial wajib.

Tabel 6. Hasil analisis Shift Share

\begin{tabular}{lrrrr}
\hline \multirow{2}{*}{ Sektor } & \multicolumn{4}{c}{ Komponen } \\
\cline { 2 - 5 } & \multicolumn{1}{c}{ Nij } & \multicolumn{1}{c}{ Mij } & \multicolumn{1}{c}{ Cij } & \multicolumn{1}{c}{ Dij } \\
\hline Sektor 1 & 53019,86 & 22116,81 & $-21593,93$ & 53542,74 \\
Sektor 2 & 17929,70 & 2199,06 & $-9030,54$ & 11098,21 \\
Sektor 3 & 240180,83 & 121287,79 & 33983,24 & 395451,87 \\
Sektor 4 & 3174,84 & 1701,77 & $-2820,49$ & 2056,11 \\
Sektor 5 & 418,14 & $-412,14$ & 1158,83 & 1164,84 \\
Sektor 6 & 37545,99 & 28838,69 & 15086,31 & 81470,98 \\
Sektor 7 & 83129,66 & 46480,81 & 15094,13 & 144704,60 \\
Sektor 8 & 22221,11 & 19731,08 & 572,89 & 42525,08 \\
Sektor 9 & 12898,12 & 8570,10 & 4855,68 & 26323,90 \\
Sektor 10 & 12370,03 & 16106,38 & 16012,87 & 44489,28 \\
Sektor 11 & 12046,91 & 10216,96 & $-888,73$ & 21375,14 \\
Sektor 12 & 5865,61 & 3510,36 & 3594,46 & 12970,44 \\
Sektor 13 & 1915,30 & 2084,74 & 140,07 & 4140,11 \\
Sektor 14 & 14048,45 & 5736,99 & $-4490,41$ & 15295,03 \\
Sektor 15 & 10689,80 & 7412,71 & 11738,99 & 29841,50 \\
Sektor 16 & 3170,37 & 2913,54 & 2225,33 & 8309,25 \\
Sektor 17 & 8978,96 & 9234,53 & 2308,22 & 20521,71 \\
\hline Total & 539603,69 & & 67946,92 & 915280,80 \\
\hline
\end{tabular}

Sumber: Olahan Penulis

Dalam Mij memungkin analisis untuk daerah yang memiliki sektor yang terkonsentrasi pada industri yang tumbuh cepat dan memiliki rataan pertumbuhan diatas sektor lain di Indonesia. Didapatkan bahwa sektor industri pengolahan, sektor perdagangan besar dan eceran, reparasi mobil dan sepeda motor, sektor konstruksi dan sektor pertanian. Hal ini menunjukan keempat sektor menjadi spesialisasi Provinsi Jawa Barat dalam pertumbuhan ekonominya. Sedangkan nilai Nij yang positif didapatkan bahwa Provinsi Jawa Barat memiliki perekonomian yang tumbuh cepat sebesar Rp 539.603 milyar rupiah.

Provinsi Jawa Barat terdiri memiliki 27 Kabupaten dan Kota yang memiliki ekonomi basis yang berbeda-beda. Dalam tingkat daerah, kabupaten dan kota di Jawa Barat memiliki karaktestik regional yang berbeda, seperti regional priangan timur memiliki kecenderungan sektor pertanian, sektor priangan barat yang condong pada industri pengolahan, serta wilayah Kota Bandung sekitarnya yang menjadi pusat 
ekonomi jasa dan perdagangan. Hal ini bersifat heterogen maka dengan menganalisisnya dalam tipologi klassen dapat dilihat beberapa kecenderungan pertumbuhan ekonomi sektoral di kabupaten dan kota serta bagaimana strategi ekonomi yang efektif untuk kabupaten dan kota yang dikualifikasikan.

Dengan melihat laju pertumbuhan ekonomi kabupaten dan kota di Jawa Barat, serta melihat besaran PDRB sektoral di masing-masing kabupaten dan kota tersebut maka didapatkan hasil kualifikasi tipologi Klassen yaitu sebagai berikut:

Gambar 4. Kuadran Kualifikasi Tipologi Klassen Tahun 2019 Kabupaten/Kota di Provinsi Jawa Barat

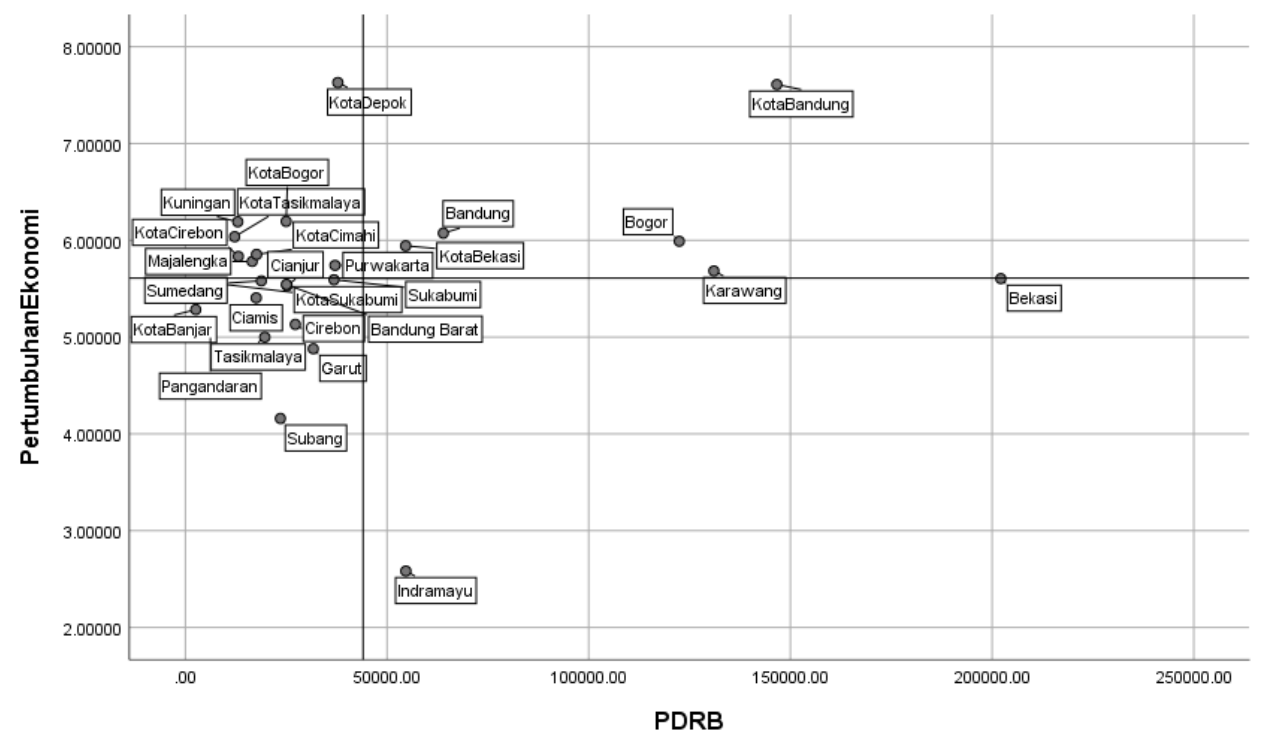

Sumber: Dokumen Penulis

Kuadran I sebagai daerah yang maju dan tumbuh pesat pada periode 2010-2019 adalah wilayah Kabupaten Bandung, Kabupaten Bogor, Kota Bandung, Kabupaten Karawang, Kabupaten Bekasi dan Kota Bekasi. Hal ini menggambarkan bahwa daerah tersebut memiliki kemandirian ekonomi dan produktifiktas yang baik sehingga bisa unggul dari wilayah lainnya. Kuadran II sebagai daerah maju namun tertekan adalah wilayah Kota Cimahi; Kota Depok; Kabupaten Majalengka; Kabupaten Kuningan, Kota Bogor, Kota Tasikmalaya, Kota Cirebon, Kabupaten Cianjur dan Kabupaten Purwakarta. 
Tabel 6. Hasil Analisis Tipologi Klassen Kabupaten dan Kota di Provinsi Jawa Barat Periode 2010-2019

\begin{tabular}{ll}
\hline Kuadran II & Kuadran I \\
Kota Cimahi; Kota Depok; Kabupaten & Kabupaten Bandung; Kabupaten Bogor; \\
Majalengka; Kabupaten Kuningan; Kota & Kota Bandung; Kabupaten Karawang; \\
Bogor; Kota Tasikmalaya; Kota Cirebon; & Kabupaten Bekasi; Kota Bekasi; \\
Kabupaten Cianjur; Kabupaten Purwakarta & \\
\hline Kuadran III & Kuadran IV \\
Kabupaten Tasikmalaya; Kota Banjar; & Kabupaten Indramayu; \\
Kabupaten Ciamis; Kabupaten Bandung & \\
Barat; Kabupaten Garut; Kabupaten & \\
Cirebon; Kabupaten Subang; Kota & \\
Sukabumi; Kabupaten Sumedang; & \\
Kabupaten Pangandaran; Kabupaten & \\
Sukabumi $\quad$ Kabumi &
\end{tabular}

Sumber: Olahan Penulis

Kuadran III sebagai daerah relatif tertinggal yaitu meliputi daerah Kabupaten Tasikmalaya, Kota Banjar, Kabupaten Ciamis, Kabupaten Bandung Barat, Kabupaten Garut, Kabupaten Cirebon, Kabupaten Subang, Kota Sukabumi, Kabupaten Sumedang, Kabupaten Pangandaran dan Kabupaten Sukabumi. Hal ini menunjukan sejumlah daerah ini mengalami perlambatan dan pertumbuhan ekonomi yang dibawah rata-rata. Maka pemerintah daerah diharapkan untuk mampu mengoptimalkan sumber daya yang dimiliki untuk dapat meningkatkan produktifitas dan pertumbuhan ekonomi untuk kemajuan daerahnya masing-masing. Kuadran IV sebagai daerah berkembang cepat meliputi Kabupaten Indramayu, maka pemerintah daerah diharapkan dapat memacu pertumbuhan dan pembangunan ekonomi yang telah dilakukan dengan mendorong faktor potensial pembangunan daerah yang berkelanjutan.

\section{Lingkungan dan Hipotesis Environmental Kuznets Curve di Provinsi Jawa Barat}

Tabel 4. Hasil Analisis Hipotesis Kurva Kuznets isu Lingkungan

\begin{tabular}{|c|c|c|c|c|c|}
\hline \multirow{2}{*}{ Sampel } & \multicolumn{2}{|c|}{ Nilai Koefisien } & \multirow{2}{*}{\multicolumn{3}{|c|}{ Posisi }} \\
\hline & PDB & $\mathrm{PDB}^{2}$ & & & \\
\hline Emisi $\mathrm{CO}^{2}$ & $-1,060 \mathrm{E}-6$ & $-3,141 \mathrm{E}-13$ & $\begin{array}{l}\text { Tidak } \\
\text { terbalik }\end{array}$ & Terjadi & $\mathrm{U}$ \\
\hline
\end{tabular}

Sumber: Olahan Penulis

Hasil uji hipotesis pada isu lingkungan menunjukan bahwa di Provinsi Jawa Barat tidak terbukti terjadinya $U$ terbalik pada isu lingkungan. Hal ini bermakna bahwa secara jangka panjang, pertumbuhan ekonomi di Provinsi Jawa Barat akan tetap menciptakan kenaikan pencemaran lingkungan. Hal ini dapat berarti bahwa peningkatan pertumbuhan ekonomi akan menyebabkan peningkatan pula pada pencemaran lingkungan. Dengan melihat tidak terjadi hipotesis kurva Kuznets U terbalik maka pertumbuhan ekonomi di provinsi Jawa Barat diindikasikan tidak terbukti hipotesis Environmental Kuznets Curve (EKC) berlaku di provinsi Jawa Barat. 


\section{KESIMPULAN}

Pertumbuhan ekonomi dan pembangunan ekonomi memiliki porsinya masingmasing dalam mengidentifikasi kinerja perekonomian suatu daerah. Pertumbuhan ekonomi yang terus bertambah tanpa adanya perbaikan dan perubahan pada pembangunan ekonomi maka akan menimbulkan permasalahan dualistik dan permasalahan ketimpangan dalam kehidupan sosial ekonomi masyarakat. Pembangunan ekonomi masih memberikan harapan pada pertumbuhan ekonomi untuk mampu menjadi pendorong dengan konsep bahwa "pertumbuhan ekonomi mendorong pembangunan ekonomi". Hal ini menyebabkan kualitas pertumbuhan ekonomi mesti direncakan. Perencanaan dalam mempersiapkan pertumbuhan ekonomi meliputi perencanaan sektoral dan perencanaan indikator ekonomi. Perencanaan sektoral diartikan sebagai upaya untuk merencanakan perbaikan dan mendorong tumbuhnya sektor-sektor strategis daerah (seperti sektor-sektor pada PDB atau PDRB). Selain itu, perencanaan indikator ekonomi diartikan sebagai perencanaan yang mendorong perbaikan pada indikator strategis pembangunan ekonomi (seperti perbaikan ketimpangan dan pencemaran lingkungan).

Ditemukan bahwa ekonomi basis di provinsi Jawa Barat mulai beralih dari sektor pertanian menuju sektor industri. Hal ini dibuktikan dengan ekonomi basis yang meliputi sektor industri pengolahan, sektor perdagangan, transportasi dan jasa. Selain itu terjadi potensi pertumbuhan ekonomi baru dalam sektor pengadaan air, pengolahan sampah, limbah, daur ulang, sektor konstruksi dan jasa pendidikan. Pada perkembangannya ditemukan bahwa hanya 1 kabupaten yang diindikasikan maju dari 27 kabupaten dan kota yang ada di provinsi Jawa Barat. Adapun dalam pembuktian kontribusi pertumbuhan ekonomi terhadap pengentasan ketimpangan dan penurunan pencemaran lingkungan menunjukan tren masing-masing. Untuk ketimpangan pertumbuhan ekonomi memiliki tren untuk dapat membantu penurunan ketimpangan di provinsi Jawa Barat. Sedangkan disisi lain untuk pencemaran lingkungan pertumbuhan ekonomi di provinsi Jawa Barat tidak mampu untuk menurunkan pencemaran lingkungan dan hipotesis Environmental Kuznets Curve (EKC) tidak berlaku di provinsi Jawa Barat.

Adapun rekomendasi yang disusun dari hasil penelitian mengenai isu ketimpangan dan isu lingkungan di Jawa Barat adalah sebagai berikut:

1. Pemerintah dapat mewujudkan perluasan iklim wirausaha, industri dan jasa untuk mengoptimal pertumbuhan ekonomi guna mendorong penurunan ketimpangan.

2. Pemerintah dapat mewujudkan pertumbuhan ekonomi yang ramah lingkungan dan berwawasan berkelanjutan dengan memperketat izin kegiatan produksi sektor-sektor industri dan pertambangan yang memberikan dampak buruk pada lingkungan.

3. Secara jangka panjang perlu kerja sama antara pemerintah, masyarakat dan swasta untuk bersama membuat komitmen pertumbuhan ekonomi yang berkualitas sehingga bemanfaat baik bagi pemerintah, masyarakat dan swasta. 


\section{DAFTAR PUSTAKA}

Acemoglu, D., \& Robinson, J. (2002). The Political Economy of The Kuznets Curve. Review of Development Economics, 183-203.

Adisasmita, R. (2008). Pembangunan Wilayah: Konsep dan Teori. Yogyakarta: Graha Ilmu.

Amaliawaiati, L., \& Murni, A. (2019). Ekonomika Mikro. Bandung: Refika Aditama.

Arista, T. R., \& Amar, S. (2019). Analisis Kausalitas Emisi CO2, Konsumsi Energi, Pertumbuhan Ekonomi dan Modal Manusia di ASEAN. Jurnal Kajian Ekonomi dan Pembangunan, 519-532.

Auty, R. M. (2003). Natural Resources, Development Models and Sustainable Development. Stevenage, Hertfordshire, UK: International Institute for Environment and Development (IIED).

Aydin, C., \& Esen, O. (2017). The Validity of The Environmental Kuznets Curve Hypothesis for $\mathrm{CO} 2$ Emissions in Turkey: New Evidence fom Smooth Transition Regression Approach. Journal of Social Sciences Institute, 101-116.

Creswell, J. W. (2017). Research Desighn: Pendekatan Metode Kualitatif, Kuantitatif dan Campuran. Yogyakarta: Pustaka Pelajar.

Department of Economic and Social Affairs, United Nations. (2000). Integrated Environment and Economic Accounting: An Operational Manual. New York, USA: United Nation Publication.

Djunaedi, A. (2015). Pengantar Perencanaan Wilayah dan Kota. Yogyakarta: Gadjah Mada Press.

Fasikha, Y., \& Yuliadi, I. (2018). Analisis Pengaruh Perubahan Lingkungan Terhadap Pendapatan Per Kapita di Negara-Negara ASEAN Periode 2005-2015. Journal of Economics Research and Social Sciences, 34-43.

Firdaus, I. A. (2017). Pengaruh Pertumbuhan dan Keterbukaan Ekonomi Terhadap Perubahan Kualitas Lingkungan: Analisis Enviromental Kuznet Curve (Studi Kasus Negara-Negara Anggota Regional Comprehensive Economic Partnership Tahun 1999-2014). Jurnal Ilmiah Universitas Brawijaya, 1-15.

Grafton, R. Q., Adamowicz, W., Dupont, D., Nelson, H., Hill, R. J., \& Renzetti, S. (2004). The Economics of The Environment and Natural Resources. Victoria, Australia: Blackwell Publishing.

Hanley, N., Shogren, J. F., \& White, B. (1997). Environmental Economics in Theory and Practice. London: Macmillan Press LTD.

Hilmi, D. F., Hamzah, A., \& Syahnur, S. (2014). Analisis Sektor Basis Kabupaten Kota dan Pusat Pengembangan Ekonomi Provinsi Jawa Barat. Jurnal Ilmu Ekonomi, 50-61.

Hoover, E. M., \& Giarratani, F. (2020). An Introduction to Regional Economics. West Virginia: Randall Jackson.

Hussen, A. M. (2005). Principles of Environmental Economics. New Fetter Lane, London: Routledge.

Kartiasih, F., \& Setiawan, A. (2020). Aplikasi Error Correction Mechaism dalam Analisis Dampak Pertumbuhan Ekonomi, Konsumsi Energi dan Perdagangan Internasional Terhadap Emisi CO2 di Indonesia. Media Statistika, 104-115.

Kuncoro, M. (2004). Otonomi dan Pembangunan Daerah-Reformasi, Perencanaan, Strategi dan Peluang. Jakarta: Erlangga.

Kuncoro, M. (2010). Ekonomika Pembangunan: Masalah, Kebijakan, dan Politik. Jakarta: Erlangga. 
Kuswantoro, D. P. (2009). Pembangunan Ekonomi dan Deforestasi Hutan Tropis (Mengkaji Kembali Hipotesis Environmental Kuznets Curve Menggunakan Analisis Antar Negara). Thesis Program Pasca Sarjana Fakultas Ekonomi Universitas Padjadjaran, 1-182.

Mourad, M., \& Trabulsi, H. (2019). Economic Growth Analysis of a Singapore: Simultaneous Equations Model. Journal of Business and Financial Affairs, 1-9.

Mukhlis, I., Utomo, S., Rahmani, L., \& Fernanda , Y. (2018). A Competitiveness Analysis of Economic Sector in Tuban Regency, East Java. Advance in Economics, Business and Management Research (pp. 443-452). Yogyakarta: International Conference on Economics Education, Economics, Business and Management, Accounting and Entrepreneurship (PICEEBA 2018).

Munandar, A. (2017). Analisis Regresi Data Panel Pertumbuhan Ekonomi di NegaraNegara Asia. Jurnal Ilmiah Ekonomi Global Masa Kini, 59-67.

Nafziger, E. W. (2005). Economic Development . Cambridge: Cambridge University Press.

Nikensari, S. I., Destilawati, S., \& Nurjanah, S. (2019). Studi Environmental Kuznets Curve di Asia: Sebelum dan Setelah Millennium Development Goals. Jurnal Ekonomi dan Pembangunan, 11-25.

Nurpita, A., \& Nastiti, A. (2016). Analysis of Development Disparities Inter Districts/City in Special Region of Yogyakarta (DIY) Province 2003-2013. JKAP (Jurnal Kebijakan dan Administrasi Publik), 23-37.

Opshoor, J. B. (2007). Environment and Poverty: Perspetives, Proposition, Policies. The Hague, Netherlands: Institute of Social Studies.

Oyvat, C. (2015). Structural Change and The Kuznets Hypothesis. Greenwich: Greenwich Political Economy Research Centre.

Perman, R., Ma, Y., McGilvray, J., \& Common, M. (2003). Natural Resource and Environmental Economics 3rd Edition. Essex, UK: Pearson Education Limited.

Pettinger, T. (2019, September 11). Environmental Kuznets Curve. Retrieved November 6 , 2020 , from https://www.economicshelp.org/blog/14337/environment/environmentalkuznets-curve/

Purwanta, W. (2008). De-Coupling Pertumbuhan Ekonomi dan Degradasi Lingkungan di Indonesia. Jurnal Teknologi Lingkungan, 86-92.

Quesne, T. L., \& McNally, R. (n.d.). The Green Buck: Using Economic Tools to Deliver Conservation Goals, a WWF Field Guide. UK: The WWF Sustainble Economics Network.

Ramattullah. (2019). Aplikasi Model Statistika Inferensia Dalam Pembelajaran Matematika Ekonomi. Jurnal Numeracy, 86-98.

Rany, A. P., Farhani, S. A., Nurina, V. R., \& Pimada, L. M. (2020). Tantangan Indonesia dalam Mewujudkan Pertumbuhan Ekonomi yang Kuat dan Pembangunan Ekonomi Berkelanjutan Melalui Indonesia Green Growth Program oleh BAPPENAS. JIEP, 63-73.

Rosyid, A. H., \& Mulyo, J. (2017). Hypothesis Testing on Environmental Kuznets Curve of Agricultural Sector in Java Island: Panel Data Analysis. Agro Ekonomi, 95-111.

Santoso, K. B., Hakim, L., \& Ningrum, E. R. (2018). Studi Temporal Pertumbuhan Ekonomi dan Polusi Udara. Studi Kasus: DKI Jakarta, Semarang, dan Surabaya pada Tahun 2005-2015. Jurnal Meteorologi Klimatologi dan Geofisika, 54-70. 
Saputra, D. (2016). Analisis Pertumbuhan Ekonomi dan Tingkat Ketimpangan Antar Kabupaten/Kota di Provinsi Jawa Barat. CR Journal Creative Research for West Java Development, 1-16.

Somantri, A., \& Muhidin, S. A. (2014). Aplikasi Statistika Dalam Penelitian. Bandung: Pustaka Setia.

Srihardianti, M., Mustafid, \& Prahutama, A. (2016). Metode Regresi Data Panel untuk Peramalan Konsumsi Energi di Indonesia. Jurnal Gaussian, 475-485.

Steiner, G., Stark, W., Pilz, H., \& Hutterer, H. (2000). Analysis of The Fundamental Concepts of Resource Management. Wien, Austria: GUA - Gesellschaft fur Umfassende Analysen GmbH.

Stimson, R. J., Stough, R., \& Roberts, B. (2006). Regional Economic Development: Analysis and Planning Strategy. New York: Springer Berlin Heidelberg.

Sugiyono. (2013). Metode Penelitian Kuantitatif, Kualitatif dan R\&D. Bandung: Alfabeta.

Suhartono, \& Kurnawati, T. (2013). Analisis Potensi Daerah dan Sektor Basis di Propinsi Jawa Barat. repository.ut.ac.id, 1-13.

Sukirno, S. (2004). Pengantar Teori Makroekonomi. Jakarta: RajaGrafindo Persada.

Syrquin, M. (2005). Kuznets and Modern Economic Growth Fifty Years Later. Thingking Ahead: The Future of Development Economics (pp. 1-15). Helsinki: WIDER Conference.

Tahvonen, O. (2000). Economics Sustainablitiy and Scarcity of Natural Resources: A Brief Historical Review. Washington D.C., USA: Recources for the future.

Tarigan, R. (2005). Ekonomi Regional: Teori dan Aplikasi. Jakarta: Bumi Aksara.

Tietenberg, T., \& Lewis, L. (2015). Enviromental \& Natural Resource Economics 10th Edition. New Jersey, USA: Pearson Education Limited.

Todaro, M. P., \& Smith, S. C. (2003). Pembangunan Ekonomi di Dunia Ketiga. Jakarta: Erlangga.

Widarjono, A. (2005). Ekonometrika Teori dan Aplikasi. Depok: Ekonisia.

Widianingsih, W., \& Suryantini, A. (2015). Kontribusi Sektor Pertanian pada Pertumbuhan Ekonomi di Provinsi Jawa Barat. Agro Ekonomi, 206-218.

Yani, A. (2019). Analisis Perkiraan Biaya Ekonomi Deforestasi di Kalimantan Barat. Jurnal Ekonomi Bisnis dan Kewirausahaan (JEBIK), 59-80.

Yustisia, D., \& Sugiyanto, C. (2014). Analisis Empiris Environmental Kuzntes Curve (EKC) Terkait Orientasi Energi. Jurnal Ekonomi dan Studi Pembangunan, 161170. 